\title{
18. ORGANIC GEOCHEMISTRY OF MIOCENE-PLIOCENE LAMINATED DIATOMITES ON THE EAST FLANK OF THE MID-ATLANTIC RIDGE (SITE 520, LEG 73)1
}

\author{
J. P. Herbin and G. Deroo, Institut Français du Pétrole, B. P. 311, 92506 Rueil Malmaison Cedex, France
}

\section{INTRODUCTION}

At the end of the Leg 73 cruise, at Site 520, a thick upper Miocene facies of laminated diatomite was discovered. It was hypothesized that the sediment was derived from nutrient-rich waters in a young Cenozoic anoxic basin in the open Atlantic Ocean near the MidAtlantic Ridge.

\section{SAMPLES}

The hypothesis was tested by analyzing 41 small samples of various lithofacies: nannofossil-diatom ooze, clayey nannofossil-diatom ooze, nannofossil-diatomite, laminated diatomite, and laminated clayey nannofossil-diatomite. All samples were taken from Lithologic Unit 2, between Cores 9 and 26 (256.70-390.98 m subbottom). In age, Core 9 is early Pliocene and the rest are late Miocene: Cores 10 to 17 are Messinian, Cores 18 to 25 are from the Messinian/Tortonian transition, and Core 26 is Tortonian.

\section{RESULTS}

\section{Mineral Carbon Content}

As shown in Table 1, most of the sediments from the late Miocene (Cores 12-26) have a mineral carbon content between 1.7 and $9.4 \%$, which is equivalent to a calcium carbonate content between 14 and $78 \%$, the average being $44 \%$. The mineral carbon content of the sediments from the upper part of the late Miocene and the early Pliocene (Cores 9-11) is higher: 10.2 to $11.0 \%$ (except for Core 10, Section 1, 40-42 cm, which has a mineral carbon content of $3.8 \%$ ), which corresponds to a calcium carbonate content of 85 to $92 \%$.

All the sediments can be considered to have a high carbonate content, the Pliocene sediments even more than the late Miocene ones.

\section{Organic Carbon Content}

The organic carbon content of the sediments was determined with a LECO apparatus on samples treated with acid.

More than two-thirds of the samples studied have a very low organic carbon content (between 0.08 and $0.21 \%$ ). These samples are distributed throughout both the Pliocene and the Miocene. The remaining one-third of the samples have a slightly richer organic carbon content that fluctuates between 0.26 and $0.36 \%$; these sam-

\footnotetext{
${ }^{1}$ Hsü, K. J., LaBrecque, J. L., et al., Init. Repts. DSDP, 73: Washington (U.S. Govt. Printing Office).
}

Table 1. Carbon content and petroleum potential of samples from Site 520 .

\begin{tabular}{|c|c|c|c|c|c|}
\hline $\begin{array}{c}\text { Core-Section } \\
\text { (interval in cm) }\end{array}$ & $\begin{array}{l}\text { Sub-bottom } \\
\text { depth } \\
\text { (m) }\end{array}$ & $\begin{array}{l}\text { Mineral } \\
\text { carbon } \\
\text { content } \\
\text { (wt. \%) }\end{array}$ & $\begin{array}{l}\text { Organic } \\
\text { carbon } \\
\text { content } \\
\text { (wt. \%) }\end{array}$ & $\begin{array}{c}\text { Temperature } \\
\left({ }^{\circ} \mathrm{C}\right)\end{array}$ & $\begin{array}{c}\text { Petroleum } \\
\text { potential } \\
(\mathrm{kg} \mathrm{HC} / \text { ton rock })^{\mathrm{a}}\end{array}$ \\
\hline $9-1,70-72$ & 256.70 & 10.2 & 0.11 & & \\
\hline $9-2,70-72$ & 257.20 & 10.2 & 0.12 & & \\
\hline $9, \mathrm{CC}$ & 262.00 & 9.7 & 0.12 & & \\
\hline $10-1,40-42$ & 265.90 & 3.8 & 0.13 & & \\
\hline $11-1,24-25$ & 275.24 & 11.0 & 0.11 & & \\
\hline $11-1,74-76$ & 275.74 & 9.8 & 0.10 & & \\
\hline $11-1,124-126$ & 276.24 & 10.9 & 0.08 & & \\
\hline $12-1,14-15$ & 284.64 & 5.4 & 0.13 & & \\
\hline $12-1,47-49$ & 284.97 & 3.5 & 0.13 & & \\
\hline $12-1,113-115$ & 285.63 & 7.5 & 0.15 & & \\
\hline $12-2,14-16$ & 286.14 & 5.6 & 0.12 & & \\
\hline $13-1,10-12$ & 294.10 & 9.4 & 0.11 & 375 & 0.05 \\
\hline $14-1,5-7$ & 299.05 & 4.7 & 0.27 & 405 & 0.33 \\
\hline $14-1,43-45$ & 299.43 & 6.0 & 0.16 & & \\
\hline $14-1,95-97$ & 299.95 & 3.0 & 0.21 & 353 & 0.27 \\
\hline $14-1,144-146$ & 300.44 & 4.3 & 0.21 & 372 & 0.21 \\
\hline $14-2,5-7$ & 300.55 & 5.8 & 0.16 & & \\
\hline $14-2,40-42$ & 300.90 & 5.3 & 0.19 & 361 & 0.13 \\
\hline $14-2,76-78$ & 301.26 & 5.3 & 0.19 & 365 & 0.13 \\
\hline $14-2,110-113$ & 301.60 & 6.7 & 0.14 & & \\
\hline $14-2,144-146$ & 301.94 & 4.6 & 0.26 & 388 & 0.32 \\
\hline $14, \mathrm{CC} 8-10$ & 302.55 & 3.2 & 0.21 & & \\
\hline $15-1,30-32$ & 308.80 & 3.9 & 0.20 & 401 & 0.12 \\
\hline $19-1,5-7$ & 336.55 & 1.7 & 0.29 & 395 & 0.30 \\
\hline $19-1,39-41$ & 336.89 & 4.0 & 0.34 & 374 & 0.48 \\
\hline $19-1,100-102$ & 337.50 & 3.9 & 0.33 & 359 & 0.18 \\
\hline $19-1,144-145$ & 337.94 & 4.7 & 0.34 & 384 & 0.22 \\
\hline $19, \mathrm{CC} 8-10$ & 338.08 & 5.5 & 0.34 & 355 & 0.43 \\
\hline $20-1,23-25$ & 341.73 & 9.1 & 0.16 & & \\
\hline $20-1,73-77$ & 342.23 & 8.4 & 0.17 & & \\
\hline $24-1,42-44$ & 360.92 & 6.5 & 0.20 & 351 & 0.03 \\
\hline $24-1,100-102$ & 361.50 & 5.0 & 0.18 & 411 & 0.05 \\
\hline $24-1,135-137$ & 361.85 & 3.3 & 0.29 & & \\
\hline $24-2,5-7$ & 362.05 & 4.9 & 0.17 & 390 & 0.13 \\
\hline $24-2,80-82$ & 362.80 & 8.3 & 0.14 & & \\
\hline $26-1,6-8$ & 389.06 & 3.8 & 0.35 & 388 & 0.25 \\
\hline $26-1,36-38$ & 389.36 & 4.2 & 0.18 & 354 & 0.15 \\
\hline $26-1,99-101$ & 389.99 & 3.9 & 0.29 & & \\
\hline $26-1,147-149$ & 390.47 & 5.6 & 0.28 & 360 & 0.06 \\
\hline $26-2,15-17$ & 390.65 & 7.0 & 0.36 & 389 & 0.30 \\
\hline $26-2,48-50$ & 390.98 & 6.2 & 0.31 & & \\
\hline
\end{tabular}

${ }^{\mathrm{a}} \mathrm{HC}=$ hydrocarbon.

ples are located in the Messinian and the Tortonian (Cores 14-26).

\section{Petroleum Potential}

A pyrolysis assay was conducted on raw samples with a Rock Eval apparatus (Espitalié et al., 1977).

During a pyrolysis assay, if the amount of hydrocarbons peaks at temperatures from 400 to $435^{\circ} \mathrm{C}$ the samples are considered to belong to the immature oil zone; if it peaks at 435 to $460^{\circ} \mathrm{C}$, they are considered to belong the main or mature oil zone; and if it peaks at temperatures beyond $460^{\circ}$ they are considered to belong to the cracking or gas zone. In the present study all the samples analyzed can be assigned to the early stage of the immature zone; the amount of hydrocarbons peaked in the 351 to $411^{\circ} \mathrm{C}$ range. 
The petroleum potential of these immature samples is very poor-less than $0.5 \mathrm{~kg}$ of hydrocarbons per ton of rock and often null.

A diagram of hydrogen index versus oxygen index cannot be constructed because of the low levels of organic carbon content on the one hand and the insignificant results of pyrolysis on the other.

\section{CONCLUSION}

The samples we studied do not support the hypothesis of sapropel sedimentation in an anoxic basin during the late Cenozoic near the Mid-Atlantic Ridge.
Practically all the organic matter that proceeded from siliceous or carbonated organisms oxidized when it reached the bottom, disappearing completely. The remaining organic matter has to be considered residual.

\section{REFERENCE}

Espitalié, J., Laporte, J. L., Madec, M., Marquis, F., Leplat, P., Paulet, J., and Boutefeu, A., 1977. Méthode rapide de caractérisation des roches mères, de leur potentiel pétrolier et de leur degré d'évolution. Rev. Inst. Fr. Pet., 32(1):3-40.

Date of Initial Receipt: September 1, 1982 